\title{
The Tragedy of Repressed Emotions: A Modernist Reading of Kazuo Ishiguro's The Remains of the Day
}

\author{
${ }^{1}$ Patrick Charles Alex \\ Department of Languages, College of Humanities, Samuel Adegboyega University, Nigeria \\ charlespatrick282@gmail.com
}

\begin{abstract}
Adetuyi, Chris. A.
Senior Lecturer, Department of Languages, College of Humanities, Samuel Adegboyega University, Nigeria dradetuyi@gmail.com
\end{abstract}

\begin{abstract}
:
This paper examines Kazuo Ishiguro's The Remains of the Day through the modernist lens. The paper attempts to evaluate areas of convergences and a few areas of divergences where modernist thought reflects in the novel. Kazuo Ishiguro tells the story of Stevens in sporadic recollections in disjointed timelines showing him as an asocial and dysfunctional character that is unable to enter into warm relationship with other characters especially Miss Kenton whom he hates to love but after he examines the true nature of his relationship with her at the end, he is full of regrets for suppressing his feelings for her. The novel shows several modernist tendencies such as a heavy deployment of interior monologue, a gradual revelation of the human condition, lack of objectivity, mental repression, open endedness, disintegration, and other tendencies which characterises modernist writings. Georg Lukacs's "The Ideology of Modernism" and Virginia Woolf's influential essay on modernism "Mr. Bennett and Mrs. Brown" were used as theoretical frameworks for the evaluation of the modernist conceptions in the novel. The paper reveals that the novel is modernist in many ways while it also has some aspects which are not entirely modern in a strict modernist sense.
\end{abstract}

Keywords: Modernist tendencies, Mental Repression, Repressed Emotions, Delusion, Georg Lukacs

\section{Introduction}

The Remains of the Day has been studied by several scholars and critics from different perspectives and different interpretations have been deduced from it. Terestchenko (2007) in Servility and Destructiveness in Kazuo Ishiguro's the Remains of the Day examines Stevens's devotion to duty concluding that his loyalty to his master involves 'destructive obedience', Holmes (2008) investigates the effects of war on the character of Stevens and observes that Stevens's disjointed behaviours mirror "personal and collective damage when people internalise a national ideal that entails the denial of their own emotional needs" (p.14). N. Rema (2015) discusses the unreliable first person narration and the suppression of emotions which is very close to the issues raised in this paper. However, the focus of this paper is not on emotional repression only but it dwells more on the modernist trends such as sense of disillusionment, frustration and alienation, disintegration, open endedness, etc.

Published in 1989, The Remains of the Day is Kazuo Ishiguro's third novel, the previous two being A Pale View of Hills (1982) and An Artist of the Floating World (1986). The Remains of the Day won the 1989 Man Booker Prize for fiction and it was later adapted into a successful film in 1993. He has

\footnotetext{
${ }^{1}$ Corresponding author
} 
since written others like The Unconsoled (1995), When We were Orphans (2000), Never Let Me Go (2005) and The Buried Giant (2015). He also has a collection of short stories, Nocturnes: Five Stories of Music and Nightfall (2009), many short fictions and a lot of screenplays. Most of these novels were shortlisted for the Booker Prize. In 2008, The Times magazine named Ishiguro among their list of The 50 greatest British writers since 1945 .

The Remains of the Day is told in the first person unreliable narration by Stevens an English Butler who dedicates his life to the loyal services of Lord Darlington and later, Mr. Farraday, an easy-going American gentleman. Much of the novel is concerned with Stevens's professional career and personal relationship with a former colleague, the housekeeper, Miss Kenton. As the narration progresses, increasing pieces of evidence of Miss Kenton's love for Stevens and of his for her is revealed. The plot is built around the continuous flow of thoughts, memories and re-evaluations of Stevens's life. The narration lays a great stress on what Stevens might have become if he had acted differently, for Stevens is given to a slavish sense of duty and loyalty coupled with extreme selfdenial which results in his tragic loss of 'human warmth', a feeling which he comes to discover at the end that is better his overblown definition of dignity.

Typical of Kazuo Ishiguro, his novels mostly deal with characters reliving their sad and sordid past experiences. A Pale View of Hills, for instance, deals with the post-war memories of Etsuko, a Japanese woman trying to deal with the suicide of her daughter Keiko while An Artist of the Floating World chronicles the life of an elderly man named Masuji Ono who, like Stevens, looks back over his career as a political artist of Japanese imperialist propaganda and becomes embittered and depressed. Kazuo Ishiguro has fertile imagination for characters whose lives were changed by the disastrous consequences of the Second World War, and the regrets and sorrows that the sordid recollections awaken in them. In an interview conducted by Michael and Sontheimer (2019), Ishiguro declares that he:

...remains fascinated by memory. What I would like to tackle next is how a whole society

or nation remembers or forgets. When is it healthy to remember, and when is it healthy to forget? (p.5).

Ishiguro's personal life is almost non-existent in this work. We say almost non-existent rather than say that it is non-existent at all because no writer writes without having some particles of his own life or experiences straying into his narration. Moreover, An Artist of the Floating World is set Ishiguro's birth town of Nagasaki during the period of reconstruction following the detonation of the atomic bomb in Nagasaki. Ishiguro was born on the 8th November 1954 but his family moved to England in 1960, when he was only five years old and he became a British citizen in 1982. Nagasaki is the second town to experience atomic bomb attack during the Second World War and it is this war which usually forms the backdrop of many of his novels. Although we are only given tit-bits concerning an ongoing war in the narration, the Second World War plays a significant part in The Remains of the Day. The treaty of Versailles forms part of Lord Darlington's impetus to help Germany. As a result of Lord Darlington's instinct to help the Nazis, he is manipulated by Herr Ribbentrop which then leads to his downfall. He is criticised and spat on for extending Nazi influence in England.

\section{Modernist Concepts in The Remains of the Day}

Ishiguro's straight-off manner of narration without much ado about the physical environment or great details about Darlington Hall where Stevens takes so much pride in serving Lord Darlington and later, Mr. Farraday, tends to confirms to Virginia Woolf's idea of not laying "enormous stress upon the fabrics of things." For modernist writers, the material surroundings of characters hold no potent influence on their attributes.

One of modernist narrative techniques which Kazuo Ishiguro has judiciously deployed in The Remains of the Day is the exploration of a character's memory and thoughts. Memory is a virile 
device in modernist literature, especially as it concerns characterisation. It might be more fitting to see memory as the inspiration or the impetus to the unfolding of the stories. The reader has no direct access to most of the central happenings: instead, he has to rely on what is reported or recollections. For instance, the meeting with Miss Kenton which constitutes the climax of the novel is related to the reader a day afterwards. Apart from a few intercalated dialogues and scenes, all through the narration, it is Steven's voice that takes us through memory lane to reveal to us the despair, mistakes-ridden and painful past that he has had. Stevens then acts as a unifying thread holding the many segments of the story together.

Ishiguro's use of structural device of memory in this novel allows Stevens to reveal his flaws implicitly during the narrative. Rema (2015) observes that, "the memory portrays the honeycomb through which Stevens hides his inner wishes" (p.1) All of the memories are triggered by certain scenes, which then again trigger other memories so that the structure is very convoluted and complex even though it is not always too hard to find your bearings in the story. The memory structure of narrative technique shows a high focalisation on inner thoughts and perceptions. Steven's phraseologies like "My recollection of Mr. Lewis is that of a gentleman of generous dimensions..." (Ishiguro 1989, p.89), "I recall a mist starting to set in as I crossed the lawn that afternoon" (p.160), "I recall also watching Mr. George Bernard Shaw, the renowned playwright, at dinner one evening..." (p.143), etc act as reminders of the reminiscing nature of what is being told. Sometimes, the narration goes in accordance with the fluctuations of Stevens' mind. The effect is that of fragmentation, as the time-line leaps between the various segments of Stevens' memories. The fluctuations within the narration between the past and the present enables us gain fragmentary information. The narration jumps from one period to another, drifting in a discontinuous movement that is a literary correlative of a mental stream of consciousness. Modernist writers experimented with ways of tracing the flow of characters' thoughts and subjective impressions with their stream of consciousness technique.

As a result of these sporadic recollections, Stevens does not seem to get over his painful past. His past seems to be memories which are full of lost opportunities, sadness, and regrets. Ishiguro (1990) himself observes that his protagonists:

Know what they have to avoid and that determines the routes they take through memory, and through the past. There's no coincidence that they're usually worrying over the past. They're worrying because they sense there isn't something quite right

here... but of course memory is this terrible treacherous terrain... (p.80)

Stevens seems every inch a character whose entire life has been wasted on the pursuit of the wrong values (i.e. dignity and greatness) to the exclusion of vital aspects of life like marriage and a happy family. The fact that all his memories are work memories lends credence to this point. As a result Stevens' position as butler and servant has gradually made it impossible for him to live a fulfilling life. He maintains a slavish sense of duty and dignity even till the end. Ishiguro (1989) helps define dignity within the framework of Stevens's distorted sense of dignity:

dignity' has to do crucially with a butler's ability not to abandon the professional being

he inhabits ... The great butlers are great by virtue of their ability to inhabit their professional role and inhabit it to the utmost; they will not be shaken out by external events, however surprising, alarming or vexing. They wear their professionalism as a decent gentleman will wear his suit ... It is, as I say, a matter of 'dignity'. (p. 43)

For even after the realization that he has deluded himself throughout his entire life and set on the path of recovering what 'remains', he still resorts to mastering the act of 'bantering' to better please Mr. Farraday:

I have of course already devoted much time to developing my bantering skills, but it is possible I have never previously approached the task with the commitment I might have done. Perhaps, then, when I return to Darlington Hall tomorrow... I will begin practising with renewed effort. (p.258) 
At some points, one gets the feeling that Stevens has no control over his work as all workaholics do, but rather controlled by it, therefore, never choosing his own path in life. His life is a metaphor for the clock that must keeping working to the point of death.

Stevens is a dysfunctional character trying to make sense of his traumatised existence. His character can be subjected to the psychoanalytic lens to enable us probe into the complexities of his personality. It is in tune with some modernist writers to create characters that tend to come under Freudian theory of psychoanalysis. It is important to state here that literature was powerfully influential in the wave of modernity by the theories of Sigmund Freud (1953), who argues that the mind has a 'basic and fundamental Structure', and that 'subjective experience' was based on the interplay of the parts of the mind, (p.154). We are not insinuating that Stevens is neurotic, but his sleazy memory could be interpreted as an expression of mental repression since several of the shortfalls tends to mar the credibility of the narration. Most times, it seems as if he has something to hide. This mental repression in Stevens's character is mind boggling and many instances of it littered the narration. The use and abuse of phrases such as "As I recall", "It is hard for me now to recall precisely what I overheard", and "I cannot recall precisely what I said...", "I have a feeling it may have been Lord Darlington himself who made that particular remark", "As I remember it..." all hint at uncertainty or better still, repression. In fact, at a point Stevens discloses that he is no longer sure of the accuracy of his memory: "But I see I have become somewhat lost in these old memories. This had never been my intention..." (p.167), such phraseologies undermine the confidence in his ability to recall the past with accuracy. The reader is at a loss because Stevens's distorted memory does not give the reader the confidence to hold as accurate what he claims to recall well. Moreover, this mistrust of his mercurial memories is further heightened by the emerging self-deception which, unknown to Stevens, is becoming clearer to the reader.

Several of the shortfalls in Stevens's memories of Lord Darlington mar his relationship with Miss Kenton. Stevens's inordinate loyalty to his master shows that his perception of events is distorted and that his memory has been programmed to be selective so that his main focus and priority in life is his role as a butler. His perception of Miss Kenton is biased as his attitude to Lord Darlington; in both instances, he projects a multidimensional image. He short-changes himself as well as Miss Kenton. He is at best a victim and a victimiser. This dual character of a victim and a victimiser comes out more clearly when Miss Kenton voices her regret at not spending her life with Stevens, it makes him realise how it would have been for both of them if they had been the ones to marry.

There is also the use of an unreliable first person narrator. Bad memory, blind devotion and the uncertain purpose of Stevens's writing are the main factors for Stevens's unreliability as a narrator. Rema (2015) aptly observes that "the narration is reliably unreliable as the protagonist doesn't undergo all the experience and the past events are just included as a part of the imagination of the protagonist" (p.2). The fact that he seems to be sure about a particular thing only to turn around later to doubt it often leaves the reader with a lot of confusion. Stevens often succeeds in conveying the illusions that he fully understands all sides of the issues he discusses. He always asserts that Lord Darlington was a man of great moral stature, and that he is proud to have worked in a truly distinguished house but he keeps denying ever knowing Lord Darlington which makes us believe that he does not really think Lord Darlington acted in the right way or that he patently feels shame at having been in Lord Darlington's employment. Stevens later feels that he trusted the wrong man. This confession is at once touching and devastating, for he seems to hint at saying that Lord Darlington lacks wisdom. He even uses words like "a sad waste" (p.211) to describe Lord Darlington's life. At that stage, the reader comes to the conclusion that he/she has heard the last word about Lord Darlington being a great and noble man, but no, he says again towards the end of the narration: 
Lord Darlington wasn't a bad man. He wasn't a bad man at all ... His lordship was a courageous man. He chose a certain path in life; it proved to be a misguided one....

(p.255)

Characters in modernist writing tend to have conflicting interests and opinions of issues and life. Clarissa shows the same attitude in Virginia Woolf's (1925) Mrs. Dalloway. At one time she is happy that she didn't marry Peter because he would not have given her any form of independence, but in another moment, she finds that she would have been much at ease with Peter and realises how he would have been hers if she had married him.

Since the entire narrative is written in retrospect, we are strictly limited to knowing only what Stevens wishes to disclose. However, most times, Stevens does seem not to be open to his reader. For instance, after talking with Miss Kenton, he goes to sit on a pier watching all of the coloured lights come on in the evening. A man comes up and sits next to him, Stevens has a most touching chat about his career in Lord Darlington's service and it is from this encounter that the reader comes to realise the true state of Stevens's feelings. For instance, the man offers Stevens a handkerchief which is our only clue that Stevens is crying; thus creating a sense of pathos by allowing the reader to see the narrator's flaws while being drawn to sympathise with him as well. Thus, Stevens finally breaks down, realising that he has deluded himself throughout his life without giving the reader any clue as to his mood or the true state of mind.

Lukacs's observation about the asocial nature of characters in modernist fiction aptly captures Stevens's alienated existence. Lukacs (1973) argues, "The individual, retreating into himself in despair at the cruelty of the age, may experience an intoxicated fascination with his forlorn condition" (p.728). Stevens's pursuit of dignity in his professional life completely takes over his personal life thereby suppressing his individuality which then results in absolute servitude or "forlorn condition" as observed by Lukacs. He never achieves true intimacy with people around him, not even with his father whom he appears to adore a lot. He is so placid that he is unable to offer Miss Kenton any condolence or consolation when she loses her only relative:

I could well imagine the blow the news would be to her, her aunt having been, to all intents and purposes, like a mother to her, and I paused out in the corridor, wondering if I should go back, knock and make good my omissions ... As it turned out, I did not see her again until the afternoon. ... I had preoccupied for some hours with the matter of Miss Kenton's sorrow, having given particular thought to the question of what I might best do or say to ease her burden a little. (p. 186)

This recklessly disturbing placidity is also seen when his father dies. He is so calm that he takes his time to note every unnecessary situation in the room where his father lay in state. We do not see Stevens betraying emotions the way a person who loses his father should. Instead, when he enters the room, he sees Dr. Meredith taking notes and also observes that Mrs. Mortimer is wearing her apron and that she has grease marks over the face but does not say a word about his father. This sort of situation Lukacs (1973) describes as "a mood of total impotence, of paralysis in the face of the unintelligible power of circumstance" (p.726). In fact, Stevens's care for Dupont's comfort of bringing bowls of water, bandages and salve for his aching foot takes precedence over going upstairs to see his father in his dying moment. Stevens's lack of 'human warmth' or human connection is best captured in his own words at the end of the narration:

It is now some twenty minutes since the man left, but I have remained here on this bench to await the event that has just taken place-namely, the switching on of the pier lights... A few minutes ago, incidentally, shortly after the lights came on, I did turn on my bench a moment to study more closely these throngs of people laughing and chatting behind me... But as I listened to their exchanges, it became apparent they were strangers who had just happened upon one another here on this spot behind me. Evidently, they had all paused a moment for the lights coming on, and then proceeded to fall into conversation 
with one another. As I watch them now, they are laughing merrily. It is curious how people can build such warmth among themselves so swiftly. (pp. 256-257)

The tone of the novel is often that of wishful longing or nostalgia for the past. As the story unfolds, the tone deepens into one of despair and regret as Stevens re-evaluates his past actions and decisions, and finds them very unwise. During his six-day drive from Darlington Hall to Weymouth, Stevens recalls various high points in the course of his service between 1922 to 1956 to Lord Darlington and his successor, the American who has recently bought the estate. The journey has a picaresque quality so that it serves to foster the exploration of memories and most times, sordid memories in which Stevens rereads Miss Kenton's letter, pretending to find hints of a possible return to Darlington Hall.

Stevens is an excellent example of the modernist anti-hero, i.e. the hero as an inadequate, degenerate man. The idea of presenting a hero as an inadequate, ordinary, confused, degenerate man or a rebel as against the norm of the traditional classical or Victorian concept of projecting the hero as a high-profile personality is common in modernist literature. Many modernist writers believe that by rejecting tradition they could discover radically new ways of making captivating art. Bradbury and McFarlane (1978) observes that some "modernists sought to defy expectations mainly in order to make their art more vivid, or to force the audience to take the trouble to question their own preconceptions" (p.12). Stevens neither achieves his desire of becoming a great butler nor the dignity to which his mind is much attuned to. At the end of the narrative, Stevens emerges a brokenemotional-wreck who has nothing much left. In fact, it is a fact which he acknowledges, "...I suppose I was something of a sorry disappointment. Perhaps it is indeed time I began to look at his whole matter of bantering more enthusiastically" (p.258) so that he could try to make the best of what 'remains' of his day.

It is important to take cognisance of the fact that two nationals are depicted in this novel: the English and the American. Ishiguro explores some of the differences between the old English Victorian culture; that of air-tight lip and emotionless attitude and the American culture of free expression of opinion and emotion.

There is also the depiction of the old and the new generations of English society. Ishiguro seems to shows two ways of being English that are conflicting with each other. Öztabek-Avc1 (2013) examines why Darlington exacts a lot of influence and power on Stevens's world view arguing that the butler in British fiction aptly represents 'Englishness' than any other occupation (p.93). Therefore, Stevens the aging butler of Darlington Hall, represents the older generation who embodies decorum, gracious, practical and undemonstrative manners. His difficulty in dealing with his new American master's tendency to 'bantering' and his own inability to respond in a similar relaxed manner shows his rootedness in old-fashioned values and code of conduct. Lord Darlington certainly does not speak to Stevens in any way other than a formal, almost solemn manner, giving his orders with brevity and authority. This perfectly echoes Virginia Woolf's (1966) apt distinction between the "Victorian cook" and the "Georgian cook" (p.2) in her essay, a point she made to contrast the insular and reserved attitude of the Victorian age with the convivial spirit of the Georgian age. She further observes, "Victorian cook lived like a leviathan in the lower depths, formidable, silent, obscure, inscrutable: the Georgian cook is a creature of sunshine and fresh air..." (p.2). Thus, the old service culture of butlers in England was destined to change dramatically after the two World Wars, by the time Stevens decides to change his lifestyle, the old ways are already gone forever. The manservant who refills Stevens's radiator comments that "You really must be top-notch working in a place like that, can't be many like you left, eh?" is completely accurate; it is an indication that Stevens or the era of specific employees like butler, housekeeper and so on large manor houses required before the World War II is on the verge of extinction.

Symbolism is a modernist concept marked by a belief that language is expressly symbolic in its nature. Symbolism is therefore, a major literary device enshrined in modernist writing to convey ideas allegorically. The closing of the silver polish company (Giffen and Co.) Mursden is a symbol 
for the outmoded nature of Stevens's profession. Polishing silver is no longer regarded in the new emerging Britain and so is the profession of the butler, under butler, housekeeper, etc. This is more so since Mr Farraday himself gets Stevens to reduce the size of the workers in Darlington Hall.

Stevens arrives at the guesthouse in Salisbury around four o'clock and decides to take a walk in the streets for a few hours. He visits a beautiful cathedral and he is impressed with the city. What impressed Stevens most is the view of the English countryside that he sees that morning. He says of the landscape:

The English landscape at its finest-such as I saw this morning possesses a quality that the landscapes of other nations, however, more superfiaclly dramatic, inevitably fail to possess. It is, I believe, a quality that will mark out the English landscape to any objective observer as the most deeply satisfying in the world and this quality is probably best summed up by the term 'greatness'... And yet what precisely is the greatness? ... I would say that it is the very lack of obvious drama or spectacle that sets the beauty of our land apart. What is pertinent is the calmness of that beauty, its sense of retrain. It is as though the land knows of its own beauty, of its own greatness, and feels no need to shout it. (pp.28-29)

The landscape is great because it lacks any "drama" or "spectacle", the beautiful is "calm" and has "a sense of restrain." The landscape is a symbol of all that Stevens stands for. It becomes essential to the decisions Stevens make that shape the plot of the story. The qualities that make the landscape "great" are the same qualities that Stevens thinks makes a great butler. This is seen from illustrations he draws with the story of the tiger and the butler, his father and the General, and the reprimanding of the drunken guests at the back of the car.

Another distinctive feature noticeable in most modernist writing which is deployed in this novel is the open-endedness with which the story concluded. The issues Stevens confronts are buried in the past and remain unresolved. From what we can infer from Stevens's renewed interest in learning the act of "bantering", it is clear that the story still continues.

There is also the pervading sense of loss. The sense of loss abounds for almost every character in the novel. Stevens loses his father, Miss Kenton, and eventually his hope of convincing Miss Kenton to return to Darlington Hall. Miss Kenton loses her aunt, her only relative; and loses Stevens when she leaves to marry a man she does not love. Lord Darlington loses Sir David Cardinal and his godson, Reginald Cardinal, above all, he loses his reputation and some level of sanity at the end of his life.

Denial is also another modernist feature in the novel. When Dr. Carlisle asks Stevens if he has ever worked with Lord Darlington, he denies ever doing so. Like the Biblical Peter, the third time he has done so in the novel. His initial reason was that "a meaningless whim had suddenly overtaken me at the moment" (p.128). At another moment, he explains that his denial is the wish to avoid "hearing nonsense concerning his lordship." (p.132) He explains that "I have chosen to tell white lies in both instances as the simplest means of avoiding unpleasantness." (p.132) For Stevens, denial is clearly a way of escaping the unpleasant. Thus, one is not wrong to adopt Shaffer (2008) view that, "Ishiguro's novels centre on individuals who repress knowledge about their past in order to protect themselves from painful experiences and painful wishes that they cannot face or even admit" (p.22). Denial is Stevens's coping mechanism.

Central to the narration is self-deception and repression. Stevens fails to act on his romantic feelings toward Miss Kenton because he cannot reconcile his sense of service with his personal life. Every character who meets Stevens either peels off a layer of deceit or exposes Stevens's delusion for the reader to see. A good instance of this is in the home of Mr. And Mrs. Taylor where the village folks mistake Stevens for a rich gentleman who used to be involved in international affairs and he leads them on to believe so only to be found out by a more clever character of Dr. Carlisle. 
As much as Stevens tries to suppress and repress the feelings he has for Miss Kenton, his undying love keeps peeping behind his fishy facade thereby betraying his emotions. For instance, the fact that Stevens reads Miss Kenton's letter over and over is itself a clear indication that he misses her quite alright. He is so eager to have any news of her that he repeatedly peruses the letter for hints. The extreme to which Stevens negates his emotions becomes very painful when he tells us that her marrying someone else made "the whole dreams forever irredeemable" (p.251). There can be no doubt the dream to which he refers involves Miss Kenton. The high point is seen upon hearing her words about the possibility of a life they might had together, he says that his "heart is breaking" (p.252). Stevens finally breaks down while sitting on the pier, lamenting what should have been and he admits that "it is too late to turn back the clock" (p.252). Thus, Stevens emerges a pathetic, if not, tragic figure, as he is brought down by an exaggerated adherence to his positive qualities. By hiding behind the mask of dignity, he loses opportunities to experience and enjoy meaningful political, emotional and social interactions. Part of this mask is portrayed by his emotionless use of language which conceals his inner feelings.

Finally the end comes with its crisis and catharsis for Stevens. He realises that he cannot turn back the hands of time, so he tries to see what he can make of what remains of his life. He accepts his past and what or who he has become. This conclusion seems to bring a cosmetic comfort and a temporary ending to his mental anguish.

We will like to bring our discussion to a close by examining those aspects of the novel which are not entirely modern in a strict modernist sense. Some of the artistic experimentations are not as robust and turgid as what is obtainable in Virginia Woolf's Mrs. Dalloway and do not strictly adhere to the artistic sensibility of James Joyce's stream of consciousness in a rigorous manner as seen in A Portrait of the Artist as a Young Man. For instance, in The Remains of the Day, there is focalisation on thoughts and memories quite alright but it does not follow complicated labyrinths as in Virginia Woolf's writing or James Joyce's other works like Finnegan Wake or Ulysses. The story runs in parts and the stages of development in the plot structure are carefully delineated with a neat sense of place and time.

Disjointed and fragmented characterisation which forms the core of modernist writing is more of the traditional pattern in The Remains of the Day. Contrary to Goerge Lukac's view that characters in modernist fiction negate history or lack a sense of personal history, Stevens seems to be suffering from excess of it. Lukacs (1973) argues:

This negation of history takes two different forms in modernist literature. First, the hero

is strictly confined within the limits of his own experience... secondly; the hero himself is without personal history. (p.715)

This sense of "personal history" if we understand Lukacs very well, would mean the contribution each character makes to the general good of the world. As if pre-empting Lukacs, Stevens himself says that he is putting the best in his job to make the world a better place:

I think I understand your position very well, Mr Smith. I can well understand that you wish the world to be a better place and that you and your fellow residents here should have an opportunity to contribute to the making of a better world. It is a sentiment to be applauded. I dare say it was a very similar urge which led me to become involved in great affairs before the war. Then, as now, world peace seemed something we had only the most fragile grasp of, and I wished to do my part. (p.199)

From the above revelations, it is clear that he is talking with Mr. Harry Smith, a resident of Moscombe who passionately believes that people exhibit dignity only when they accept their responsibility to vote and strongly exercise their own opinions. Though Harry Smith's view about democracy stands in sharp contrast to the elitist views of Stevens, both have a robust and generous sense of history. Dignity, he claims, is not just for gentlemen but everyone who exercises voting right. Besides, Stevens knows in what exact way an individual can make a contribution to history. 
Moreover, Stevens's work with the silver contributes to the easing of the relations between Lord Halifax and Herr Ribbentrop even if it was to have terrible political consequences later. Therefore, Stevens indirectly plays a little part in history, even if it later turns out a bad one. The problem is that he helps the Nazis without even knowing it. When Stevens goes to fetch a bottle of port from the cellar for the dignitaries, he is under the illusion that he is helping to serve men who will change history and a sense of triumphs wells up in him. Most importantly, even at the end Stevens still maintains:

the hard reality is, surely, that for the likes of you and me, there is still choice other than to leave our fate... in the hands of those great gentlemen at the hub of this world who employ our services... to make a small contribution count for something true and worthy. (p.257)

Therefore, Lukacs' position that characters in modernist literature lack a sense of history is not wholly accurate where Stevens is concerned.

\section{Conclusion}

Kazuo Ishiguro's The Remains of the Day is a literary excursion through memory and history. On the surface, there is a lingering temptation to classify the novel as a travelogue, but it is more of a historiographic metafiction which recounts Stevens's frustrations, regrets, anger and sadness which he suppresses owing to his delusion of grandeur. The title, The Remains of the day, is significant and it is open to evaluative interpretations. The title is both connotatively and denotatively responsive to the narration. Denotatively, the "Remains of the Days" technically means the evening which connotes old age; a time for sober reflections over one's life so far. However, the word "remains" in relation to Stevens's case hints at what is left after a wreck. Connotatively, The Remains of the Day could be read to mean Stevens's future service with Mr Frarraday. For Stevens himself hints at this when he decides to put renewed efforts in the act of bantering to "pleasantly surprise" Mr. Farraday on his return.

\section{Biography:}

Dr. Patrick Charles A. hails from Ipe Akoko in Ondo State in Nigeria; his research interest lies in African literature with a special focus on humour studies in oral literature, prose and drama, literary theory and criticism, popular culture and creative writing.

Dr. C. A. Adetuyi hails from Osun State Nigeria; he specialises in literary stylistics, gender studies and poetry.

\section{References:}

[1] Bradbury. M. \& McFarlane. J., eds., Modernism: A Guide to European Literature. London, United Kingdom: Penguin Books, (1978)

[2] Freud. S., The Complete Psychological Works of Sigmund Freud. (J. Strachey, Trans.), 24 vols. London: Hogarth, (1953)

[3] Gregory. M., An Interview with Kazuo Ishiguro, Contemporary Literature, Madison, WI: University of Wisconsin Press, 30(3)(1989), 335-347, https://doi.org/10.2307/1208408

[4] Holmes. F. M., Realisms, Dreams and the Unconscious in the Novels of Kazuo Ishiguro, In A. James \& C. E. Sarah (eds.), The Contemporary British Novel, (2005), pp. 11-23, https://doi.org/10.1007/978-1-34973717-8_2

[5] Ishiguro. K., The Remains of the Day, London, United Kingdom: Faber and Faber, (1989) 
[6] Lang. J., Public Memory, Private History: Kazuo Ishiguro's The Remains of the Day, Clio, 29(2)(2000), 143-165.

[7] Lukacs. G., The Ideology of Modernism. In T. Gregory (ed.) Issues in Contemporary Literary Criticism, (pp. 31 -97). New York City, NY: Little Brown and Company, (1973)

[8] Michael. M. \& Sontheimer. M., Interview with Kazuo Ishiguro. Retrieved May 10(2019), from http://tinyurl.com/3yqzy.

[9] Michel. T., Servility and Destructiveness in Kazuo Ishiguro's The Remains of the Day, Journal of Literature and the History of Ideas 5(1)(2007), 77-89, https://doi.org/10.1353/pan.0.0007

[10] Öztabek-Avc1. E., An 'Ideological Servant'? A Study of the Servant Figure in Kazuo Ishiguro's The Remains of the Day, Interactions: Ege Journal of British and American Studies 2(1)(2013), 93-103.

[11] Rema. N., The Unreliable narration and the suppression of emotions in Kazuo Ishiguro's the Remains of the Day, International Journal of Scientific and Research Publications, 5(7)(2015), 1-3.

[12] Shaffer. B. W., Understanding Kazuo Ishiguro, Columbia, SC: University of South Carolina Press, (2008)

[13] Vorda. A. \& Herzinger. K., An interview with Kazuo Ishiguro. In K. Ishiguro (ed.). Conversations with Kazuo Ishiguro (1st ed.). Jackson, MS: University of Mississippi Press, (1990)

[14] Woolf. V., Mr. Bennett and Mrs, Brown. In L. Woolf (ed.) Collected Essays (1st ed.), 319-337. London, United Kingdom: Hogarth Press, (1966)

[15] Woolf. V., Mrs Dalloway, London, United Kingdom: Hogarth Press, (1925) 